\title{
Non-Realist Cognitivism, Truth and Objectivity
}

\author{
Jussi Suikkanen ${ }^{1}$
}

Received: 16 February 2016 / Accepted: 15 June 2016 / Published online: 12 July 2016

(C) The Author(s) 2016. This article is published with open access at Springerlink.com

\begin{abstract}
In On What Matters, Derek Parfit defends a new metaethical theory, which he calls non-realist cognitivism. It claims that (i) normative judgments are beliefs; (ii) that some normative beliefs are true; (iii) that the normative concepts that are a part of the propositions that are the contents of normative beliefs are irreducible, unanalysable and of their own unique kind; and (iv) that neither the natural features of the reality nor any additional normative features of the reality make the relevant normative beliefs true. The aim of this article is to argue that Parfit's theory is problematic because its defenders have no resources to make sense of the nature of normative truth, which is an essential element of their view. I do this by showing how the traditional theories of truth are not available for the non-realist cognitivists.
\end{abstract}

Keywords Metaethics $\cdot$ Normativity $\cdot$ Derek Parfit $\cdot$ Non-realist cognitivism $\cdot$ Truth

\section{Introduction}

In On What Matters, Derek Parfit draws the following map of the metaethical landscape (Parfit 2015, 13; Parfit 2011, vol. 2, 263) ${ }^{1}$ :

$\left[\mathrm{Q}_{1}\right]$ Are normative claims intended or believed to state truths?

Yes-conceptual cognitivism; no- $\left[\mathrm{T}_{1}\right]$ non-cognitivism

\footnotetext{
${ }^{1}$ All references to the third volume of On What Matters are to the page numbers of the 16 January 2015 version of the volume.
}

Jussi Suikkanen

j.v.suikkanen@bham.ac.uk

1 University of Birmingham, Birmingham, West Midlands, UK 
$\left[\mathrm{Q}_{2}\right]$ [Assuming that conceptual cognitivism is true], are there any normative truths?

Yes - substantive cognitivism; no- $\left[\mathrm{T}_{2}\right]$ nihilism/error theory

$\left[\mathrm{Q}_{3}\right]$ [Assuming that substantive cognitivism is true], are these truths irreducibly normative?

If the answer to $\mathrm{Q}_{3}$ is yes, $\left[\mathrm{Q}_{4}\right]$ do [the irreducibly normative] truths have ontological implications?

Yes- $\left[\mathrm{T}_{3}\right]$ metaphysical non-naturalism; no- $\left[\mathrm{T}_{4}\right]$ non-realist cognitivism

If the answer to $\mathrm{Q}_{3}$ is no, $\left[\mathrm{Q}_{5}\right]$ are the concepts and claims with which we state such truths irreducibly normative?

Yes $-\left[\mathrm{T}_{5}\right]$ non-analytical naturalism; no- $\left[\mathrm{T}_{6}\right]$ analytical naturalism

Parfit's own answers are "yes" to $\mathrm{Q}_{1}, \mathrm{Q}_{2}$ and $\mathrm{Q}_{3}$ and "no" to $\mathrm{Q}_{4}$. He thus defends $\mathrm{T}_{4}$, which he called first "non-metaphysical cognitivism" (Parfit 2011, vol. 2, 479) and which he now calls "non-realist cognitivism" (Parfit 2015, 15). Parfit's case for $\mathrm{T}_{4}$ is an argument from exclusion (Parfit, vol. 2, chapters 24-36; Parfit 2015, chapters 1-11). He tries to show that, because $T_{1}, T_{2}, T_{3}, T_{5}$ and $T_{6}$ fail, we should accept non-realist cognitivism.

Parfit quickly excludes nihilism $\left[\mathrm{T}_{2}\right]$, a view also known as the error theory. It claims that, because normative properties are not instantiated, it is, for example, not the case that we have reasons to avoid future agony. ${ }^{2}$ Parfit is convinced that there are some normative truths such as the truth that we do have reasons to avoid future agony. He also thinks that, without such truths, nothing would matter in the normative reasoninvolving sense, which would be too bleak (Parfit 2011, vol. 2, 619-620). Furthermore, if you share Parfit's previous conviction, then you are epistemically entitled to reject nihilism until you have been provided with sufficiently good epistemic reasons to give up your conviction. However, any such epistemic reasons would arguably show that there are normative truths (Parfit 2011, vol. 2, 293 and 619). ${ }^{3}$

The second view that Parfit excludes is metaphysical non-maturalism $\left[\mathrm{T}_{3}\right] .{ }^{4}$ According to it, there are normative facts which do not depend for their existence on our stance towards them. No matter what we think, we always have reasons to avoid future agony. One part of this fact is a robust, worldly normative reason-relation between future agony and our attempts to avoid it. Such counting-in-favour-of relations are, on this view, irreducible and of their own unique kind. They are not empirically observable, causally efficacious, or a part of the subject matter of sciences. Despite this, according to $T_{3}$, the reason-relations are a part of the fundamental structure of the world.

\footnotetext{
${ }^{2}$ For recent defences, see Joyce (2001) and Olson (2014).

${ }^{3}$ A similar objection is developed in Cuneo (2007). For a response, see Olson (2014, 155-172).

${ }^{4}$ Recent book-length defences include Enoch (2011), Shafer-Landau (2003) and Wedgwood (2007).
} 
Parfit's first objection to this view is that an additional normative layer of reality is "too queer to be compatible with a scientific world view" (Parfit 2011, vol. 2, 486 and 465; Parfit 2015, 15). This extra normative reality also raises familiar epistemic questions about how we could ever know about it even if it existed. Parfit's second objection relies on analogies. According to him, there are necessary truths in mathematics and logic (Parfit 2011, vol. 2, 475485; Parfit 2015, 130). There are even truths about what could exist and happen (Parfit 2011, vol. 2, 467). In these cases, according to Parfit, the relevant propositions can be necessarily true without any additional independently existing entities or properties such as numbers or possible worlds (Parfit 2011, vol. 2, 479; Parfit 2015, 93, 99, 113 and 129-130). The thought then is that, given the similarities between normative truths and the previous truths, the normative truths do not need to be based on an independently existing layer of reality either. ${ }^{5}$

Parfit argues carefully against all other alternatives to non-realist cognitivism. In the second volume of On What Matters, chapters $99-104^{6}$ are against noncognitivism $\left[\mathrm{T}_{1}\right]$, chapters $83-84$ against analytical naturalism $\left[\mathrm{T}_{6}\right]$, and chapters 87-88 and 91-98 against non-analytical naturalism $\left[\mathrm{T}_{5}\right] .{ }^{8}$ There are already three volumes of critical evaluations of On What Matters in which leading noncognitivists and naturalists defend their views against Parfit's objections. ${ }^{9}$ Parfit himself is using the third volume of On What Matters (i) to clarify his objections, (ii) to develop further objections to the non-cognitivist and naturalist responses and (iii) to find common ground between his view and the other alternatives (Parfit 2015, chapters 1-11).

\footnotetext{
${ }^{5}$ On their surface, mathematic truths and modal truths both appear to posit entities such as numbers and possible worlds which too could be argued to be incompatible with a scientific world view. Parfit fails to acknowledge this potential tension between his first objection to metaphysical non-naturalism and the metaphysical implications of the mathematical and modal truths, which he uses as a model for normative truths. This is perhaps explained by Parfit's prior commitment to the idea that the surface appearance of mathematical and modal truths is misleading metaphysically speaking. The thought is that which mathematical and modal claims are true can be decided independently of which numbers or possible worlds, if any, exist (Parfit 2011, vol. 2, 479-480). If we reject this assumption, we cannot rely on mathematics and modality as a model for normative truths whilst, at the same time, endorsing Parfit's first objection to metaphysical nonnaturalism

${ }^{6}$ Parfit argues that non-cognitivism cannot (i) make sense of disagreement (Parfit 2011, vol. 2, 385), (ii) describe our practical reasoning accurately (Parfit 2011, vol. 2, 386), (iii) explain normative mistakes (Parfit 2011, vol. 2, 389-400) or (iv) make sense of what it is for actions to be rational (Parfit 2011, vol. 2, 404-405), and (v) accepting it would make us blind to normative truths about reasons (Parfit 2011, vol. 2, 409, 458).

${ }^{7}$ The main objection is that defenders of such views fail to offer substantive normative views, and instead, they can only put forward trivial concealed tautologies or make psychological claims (Parfit 2011, vol. 2, 277, 283-285, see also Parfit 2011, vol. 1 chapter 10, especially 72).

${ }^{8}$ Parfit's objections to these views are (i) that they lead to the elimination of morality and normativity (Parfit 2011, vol. 2, 303-304, 324-327), (ii) the fact stating argument (Parfit 2011, vol. 2, 338-341), (iii) the triviality objection (Parfit 2011, vol. 2, 341-344 and 357-358) and (iv) the lost property objection (Parfit 2011, vol. 2, 344-345 and 359).

${ }^{9}$ See Suikkanen and Cottingham (2009), Singer (2016) and Kirchin (forthcoming). Defences of noncognitivism include Lenman (2011), Blackburn (2016) and Gibbard (2016), defences of analytical naturalism include Smith (2016) and Jackson (2016), and defences of non-analytical naturalism include Copp (forthcoming), Dowell and Sobel (forthcoming), Laskowski (2015), Markovits (forthcoming), Railton (2016) and Schroeder (2016).
} 
So far, very few philosophers have focussed on Parfit's own theory, nonrealist cognitivism $\left[\mathrm{T}_{4}\right],{ }^{10}$ because Parfit's critics have mainly been interested in Parfit's objections to their own views. Parfit's own proposal, however, also deserves critical attention already because which metaethical view we should accept is a function of the theoretical costs and benefits of all the alternatives (Parfit 2011, vol. 2, 264). For this reason, I will focus here solely on non-realist cognitivism. I argue that its defenders cannot make sense of the truth of normative truths. The next section briefly outlines Parfit's theory. "Correspondence Theories and Deflationism" section explains how it explicitly rules out the most popular theories of truth: different versions of correspondence theories and deflationism. "Coherentism and Pragmatism" section then argues that coherentist and pragmatist views of truth commit non-realist cognitivism to an objectionable type of first-order relativism. This means that non-realist cognitivists are left with epistemic theories of truth and primitivism, which are explored in the concluding "Epistemic Theories of Truth and Primitivism" section.

\section{Parfit's Non-Realist Cognitivism}

This section describes Parfit's non-realist cognitivism as it emerges from his answers to the questions $\mathrm{Q}_{1}$ to $\mathrm{Q}_{4}{ }^{11}$ In $\mathrm{Q}_{1}$, Parfit attempts to use whether we intend to state truths to draw the distinction between cognitivism and non-cognitivism (Parfit 2011, vol. 2, 263-265; Parfit 2015, 13-16). I will explain below why this is not a good idea. Instead, it is much easier to understand cognitivism as the view according to which normative judgments are beliefs whereas according to non-cognitivism, they are some types of desire-like attitudes. ${ }^{12}$ We can then draw the distinction between beliefs and desire-like attitudes in terms of their directions of fit. ${ }^{13}$ Beliefs have the mind-to-world direction of fit (which makes them satisfy their functional role when they fit how the world is), whereas desire-like attitudes have the world-to-mind direction of fit (which makes them satisfy their functional role when the world is made to fit them).

\footnotetext{
${ }^{10}$ Parfit attributes this view also to Thomas Nagel and T.M. Scanlon (Parfit 2011, vol. 2, 486; Parfit 2015, 132). Parfit ascribes the view to Nagel on the basis of Nagel $(1996,205)$ but gives no references to Scanlon (but see Scanlon (2014, chapter 2)). A similar view has also been defended by Skorupski (2006), who claims that normative propositions have truth conditions and can be true even if they are not in the business of trying to depict any substantial truth-making facts. The best critical investigations of these views so far have been written by Tristram McPherson (2011) and Jonas Olson (forthcoming). McPherson focuses on Scanlon but also acknowledges that his objections apply to Parfit and Nagel too (McPherson 2011, 224, fn. 3). His main objection to non-realist cognitivism is that it is unable to explain the authority of normative standards in deliberation. Olson, in contrast, argues that Parfit must be committed to many different senses of "exist" some of which are metaphysically loaded and some of which are not (see fn. 16 below). Olson then claims that it is difficult to make sense of the latter type of senses of exist.

${ }^{11}$ See Parfit (2011, vol. 2, 479-487, 502 and 747-749) and (2015, 15-16, 94-95, 99, 111-115 and 122-132).

12 This orthodox way of describing non-cognitivism follows Schroeder (2010, 10-12). By "normative judgment", I mean the mental state in virtue of which one counts as sincerely accepting a sentence, which can be used to make an assertion with normative content. For canonical non-cognitivist views, see Blackburn (1993 and 1998) and Gibbard (1990 and 2003). For a detailed book-length overview and extensive bibliography, see Schroeder (2010).

${ }^{13}$ The idea of directions of fit originates from Anscombe (1957) and Platts (1979, 256-257).
} 
Parfit too accepts this way of drawing the distinction. He notes that, unlike the noncognitivists, most of us think that moral beliefs are beliefs (Parfit 2011, vol. 2, 380). He also denies that moral beliefs have any necessary connection to motivation in the way that desire-like attitudes have (Parfit 2011, vol. 2, 382). And, he acknowledges that according to non-cognitivists, value judgments express desires (Parfit 2011, vol. 2, 391). Given that Parfit's non-realist cognitivism is a form of cognitivism, we should then think that according to this position, normative judgments are beliefs with the mind-to-world direction of fit.

I will set $\mathrm{Q}_{2}$ aside too. Parfit's answer to it merely states that some normative beliefs are true. This only tells us that non-realist cognitivism is not a version of nihilism. In explaining the rest of the features of non-realist cognitivism, I will not rely on Parfit's questions $\mathrm{Q}_{3}$ to $\mathrm{Q}_{5}$ (“are normative truths irreducibly normative?", "do the irreducible normative truths have ontological implications?", and "are the concepts and claims with which we state such truths irreducibly normative?") either because doing so would require taking a stand on controversial issues discussed later on. Instead, it is easier to understand Parfit's position through how it disagrees with the remaining alternatives metaphysical non-naturalism $\left[\mathrm{T}_{3}\right]$, non-analytical naturalism $\left[\mathrm{T}_{5}\right]$ and analytical naturalism $\left[\mathrm{T}_{6}\right]$.

According to analytical maturalism $\left[\mathrm{T}_{6}\right]$, when we consider the propositions which are the contents of our normative judgments, the concepts that constitute them are ordinary concepts that we also employ when we think about the empirically observable physical world. ${ }^{14}$ Thus, according to $\mathrm{T}_{6}$, the proposition <WE HAVE REASONS TO AVOID FUTURE AGONY> is identical with and reducible to some proposition of the form $<$ (WE)R(FUTURE AGONY) > where "R" stands for a two-place relational predicate concept that can also be expressed by using non-normative vocabulary. Non-realist cognitivism rejects analytical naturalism. It holds that normative propositions and their constituent normative concepts are irreducible and of their own unique kind (Parfit 2011, vol. 2, 266, Parfit 2015, 19-21).

As explained above, according to metaphysical non-naturalism $\left[\mathrm{T}_{3}\right]$, there are normative facts which obtain in virtue of actions and states of affairs instantiating irreducible, sui generis normative properties that are an additional part of the basic structure of the reality. This view then claims that these normative facts make some of our normative beliefs with irreducible normative contents true. Non-analytical naturalism $\left[\mathrm{T}_{5}\right]$, in contrast, claims that, even if normative propositions have irreducible normative contents, some of these propositions are still made true by the natural facts of the world. ${ }^{15}$ Thus, even if the proposition <WE HAVE REASONS TO AVOID FUTURE AGONY > cannot be expressed with non-normative vocabulary, the fact that makes this proposition true can still be an ordinary natural fact such as the fact that, if we were fully informed and coherent, we would try to avoid future agony.

Parfit's non-realist cognitivism rejects both metaphysical non-naturalism and nonanalytical naturalism because it denies that the true irreducible normative propositions need to be made true by any part of the reality (Parfit 2011, vol. 2, 486-487; Parfit $2015,14-15)$. The view claims that some of those propositions are true even if they are

\footnotetext{
${ }^{14}$ See Finlay (2014, especially chapter 4), Jackson (1998), Smith (1994) and Williams (1979).

${ }^{15}$ Canonical defences of non-analytical naturalism include Boyd (1988), Brink (1989), Schroeder (2007) and Sturgeon (1988).
} 
not made true by any natural facts or sui generis normative facts. Hence, on this view, the truth of irreducible normative propositions does not have any metaphysical or ontological implications. The truth of propositions such as <WE HAVE REASONS TO AVOID FUTURE AGONY> is independent of what properties and facts are a part of the fundamental structure of the reality. ${ }^{16}$

Non-realist cognitivists are then committed to the following:

1. Normative judgments are beliefs.

2. Some normative beliefs are true.

3. The normative concepts that are a part of the propositions that are the contents of normative beliefs are irreducible, unanalysable and of their own unique kind.

4. Neither the natural features of the reality nor any additional normative features of the reality make normative beliefs true. ${ }^{17}$

We should then ask: of what does the truth of the relevant irreducible normative truths then consist? What is, on this view, the difference between the true normative propositions and the ones that are not true?

\section{Correspondence Theories and Deflationism}

Let us begin from two most popular theories of truth: the correspondence theories and versions of deflationism. This section briefly explains these theories and why they are not available for the non-realist cognitivists.

The basic crux of the correspondence theories is easy to state even if the basic tenets of these theories quickly lead to complications. ${ }^{18}$ Roughly, on these views, the truth of true propositions consists of their correspondence to how things are. The problem with stating these views in this way is that most theories of truth can accommodate the

\footnotetext{
${ }^{16}$ One small qualification has to be added here. When it is true that we have reasons to avoid future agony, there is a sense - "a description-fitting sense"-in which, according to Parfit, future agony has the relational property of being a reason for us to avoid it (Parfit 2015, 16-28). When we talk of properties in this sense, normative properties merely mirror the relevant true propositions, but they are not a part of the structure of the reality in any ontologically weighty and explanatory sense. In this wide lightweight sense, according to Parfit, irreducible normative facts and properties are unavoidable, non-problematic and even acceptable to nonanalytical naturalists and non-cognitivists (Parfit 2015, 46-47, 91). Parfit emphasises that properties and facts in this sense do not have an ontological status, not even a lesser one (Parfit 2015, 91), but rather they are more like mere projections of the normative truths that are prior in the order of explanation (Parfit 2011, vol. 2, 749). For criticism based on the obscurity of this different sense in which the reason relations are meant to exist, see Olson (forthcoming, Sect. 3.1).

${ }^{17}$ It could perhaps be argued that there is tension between the claims 3 and 4 here. The argument would be that it would be difficult for Parfit to put forward the claim 3 about the unanalysability of normative concepts whilst, at the same time, endorsing 4 because advancing 4 as the metaphysical claim according to which normative truths do not have truth makers comes close to involving at least a partial analysis of normative concepts.

${ }^{18}$ An expression of this theory can be found from the major historical figures from Plato and Aristotle to Descartes and Hume (David 2015, Sect. 1.1). Canonical modern defences include Moore (1953 [1910], chapter 15), Russell (1912, 129), Austin (1970 [1950]) and Alston (1996). For overviews, see David (2015), Engel (2002, 14-26) and Künne (2003, chapter 3).
} 
previous platitude (Wright 1992, 25). For this reason, it is not sufficient to use mere correspondence to how things are to explain the correspondence theories.

It is better to begin from the idea that according to the correspondence theories truth is a relational property. According to them, the truth of a proposition consists of there being a "chunk of reality" such that the proposition is in a "correspondence" relation with it. The challenge for the correspondence theorists is then to give an informative account of the nature of the relevant chunk of reality and the correspondence relation.

Let us use the proposition <WE HAVE REASONS TO AVOID FUTURE AGONY> to illustrate one response to this challenge. ${ }^{19}$ It claims that, when this proposition is true, a chunk of the external reality must be a genuine fact that we have reasons to avoid future agony. For the proposition then to be true, the concepts of the proposition WE, TO AVOID, FUTURE AGONY, and HAVING REASONS must refer to the constituents of the relevant fact: us, actions of avoidance, future agony and the relevant reason-relations. Furthermore, the structure in which these constituents form the fact must be isomorphic with the structure of the proposition which the relevant concept form. If this is the case, then the correspondence relation obtains and the proposition is true.

This theory is clearly not available for the non-realist cognitivists. They explicitly deny that there is a chunk of reality that is the normative fact that we have reasons to avoid future agony. This is why they cannot use a relation to such a fact to explain of what the truth of normative propositions consists. ${ }^{20}$ To his credit, Parfit recognizes this. He defines alethic realism as the view that "[a]ll truths are made to be true by the way in which they correctly describe how things are in some part of reality" (Parfit 2015, 14; Parfit 2011, vol. 2, 745). This view encapsulates the essence of the correspondence theories. Parfit then explicitly states that accepting non-realist cognitivism is a way of rejecting alethic realism (Parfit 2011, vol. 2, 746; Parfit 2015, 15). By doing so, Parfit explicitly rules out the compatibility of correspondence theories of truth and non-realist cognitivism.

Let us then turn to the second popular family of theories of truth, the so-called deflationist views. ${ }^{21}$ These theories are not so much theories of the property of being true as views about the meaning of the truth predicate. Roughly, according to them, this predicate makes no essential contribution to the sentences in which it is used. It is a transparent predicate in that the meaning of the sentences " $p$ " and "it is true that $p$ " is the same, which explains why we are willing to accept all non-pathological instances of the T-schema "the proposition <THAT P $>$ is true if and only if p". Deflationists then add that the transparent truth predicate can still play a useful role in linguistic communication. We can use it to express our agreement with sets of propositions ("everything in the Bible is true") and with ones that are not explicitly expressed in the context ("what he first said is true"). In these cases, the truth predicate enables us to make a semantic

\footnotetext{
19 This response is inspired by Wittgenstein (1961 [1921]). Not all responses to the previous challenge rely on facts and isomorphism, but instead, they use other, often causal ways of characterising the relevant chunk of reality and correspondence (Wright and Pedersen 2010, 211).

${ }^{20}$ For the same reason, non-realist cognitivism is not compatible with the identity theories of truth either. These theories claim that true propositions just are chunks of reality (Hornsby 1997).

${ }^{21}$ Different versions are also known as forms of minimalism, disquotationalism, expressivism, prosententialism, redundancy theory, performative theory, disappearance theory and no truth theory. Canonical defences include Field (1986), Grover (1992), Horwich (1990) and Ramsey (1927). For overviews, see Engel (2002, chapter 2), Künne (2003, 56-92) and Stoljar and Damnjanovic (2010).
} 
descent from talking about language (what was written in bible) to talking about the world (things are in that way).

Deflationists claim that these observations about the truth predicate tell us all we need to know about truth. Once we know how the predicate functions, we can recognize that truth is not a genuine property or a relation. It does not have a real essence or nature that could be captured by a philosophical theory. At best, the predicate "...is true" can ascribe a logical, formal "quasi-property" to propositions (Horwich 1990, Sect. 2.9). Let us then consider why this view is not available for the non-realist cognitivists.

It is well known that non-cognitivists endorse deflationism. ${ }^{22}$ They thus think that the sentence "it is true that we have reasons to avoid future agony" means the same as "we have reasons to avoid future agony". Here, the non-cognitivists who think that the latter sentence expresses the speaker's desire-like attitudes will think that the first sentence does exactly the same. To his credit again, Parfit is aware of this connection between non-cognitivism and deflationism (Parfit 2011, vol. 2, 380-381; Parfit 2015, 101 and 124-125).

In this situation, it is peculiar that Parfit attempts to rely on the notion of truth to draw the distinction between cognitivism and non-cognitivism in $\mathrm{Q}_{1}$. After all, in $\mathrm{Q}_{1}$, he draws the distinction by asking whether normative claims are intended and believed to state truths. Here, Parfit must be assuming that being true is a genuine substantial property given that in the deflationary sense the non-cognitivists will insist that normative claims are intended and believed to state truths. This means that, insofar as Parfit wants to continue to use $\mathrm{Q}_{1}$ to distinguish non-cognitivism from cognitivism, he cannot rely on deflationism about truth in his non-realist cognitivism. ${ }^{23}$

Parfit and other non-realist cognitivists would not, however, need to commit themselves to an inflated property of being true when they distinguish non-cognitivism from cognitivism. They can draw this distinction perfectly well in the standard way by considering the different functional roles which normative judgments play according to these views as I discussed at the outset of this article (see the beginning of Sect. 2 above). $Q_{1}$ should thus be the question of whether normative judgments are beliefs or desire-like attitudes. The question then is: if the non-realist cognitivists drew the distinction between cognitivism and non-cognitivism in this psychological way, could they then use deflationism about truth to make sense of normative truth? Could they, in this case, think that, when a normative proposition is true without being made true by a chunk of reality, the use of the truth predicate in this context should be understood in the deflationary way?

The reason why the answer to these questions is "no!" is that, if the non-realist cognitivists attempt to be deflationists about truth, they will face a dilemma. Either the non-realist cognitivists who also endorse deflationism about truth are deflationists in addition about normative facts or they understand these facts in a more inflationary way. The problem is that either way, the combination of non-realist cognitivism and deflationism faces decisive objections.

\footnotetext{
$\overline{22}$ See, for example, Blackburn (1998, 78-79) and Gibbard (2003, 60-65). For a thorough overview, see Schroeder (2010, chapter 8).

${ }^{23}$ Parfit's objection to the combination of non-cognitivism and deflationism is that the non-cognitivists who endorse deflationism will be unable to distinguish their view from realist forms of cognitivism (Parfit 2015, 102 and 125). This is not quite right given that the non-cognitivists can explain what is distinctive about the view by relying on the practical functional role which normative judgments play according to them (see Sect. 2 above)
} 
We must first note that it will be very difficult for the non-realist cognitivists who accept deflationism about truth to understand our talk of normative facts also in the same deflationary way (see Strawson 1950, Sect. 2). If asserting the sentence "it is a fact that we have reasons to avoid future agony" merely amounted to saying that we have reasons to avoid future agony, these non-realist cognitivists could not distinguish their view from metaphysical non-naturalism. In this situation, it would make no sense for the non-realist cognitivists in question to insist, as they do, that metaphysical nonNaturalism is false because there are no normative facts that make our normative claims true. After all, understanding the talk of these facts in the deflationary way would not add anything to what the non-realist cognitivists are already committed.

Therefore, in order to distinguish their view from metaphysical non-naturalism, the nonrealist cognitivists who accept deflationism about truth must (i) understand normative facts in an inflationary way (they would be a genuine part of the reality if they existed) and they must also (ii) think that such facts do not obtain. This leads to the second horn of the dilemma. In this case, the non-realist cognitivists would be claiming that we have reasons to avoid future agony and that it is true (in the deflationary way) that we have those reasons even if no part of the reality is the (inflated) fact that we have reasons to avoid future agony.

The main problem with this combination of views is that it collapses non-realist cognitivism into the conservationist versions of moral error theory, which have been defended by J.L. Mackie (1977, 16, 22, 48-49 and part 2), Charles Pigden (Pigden 2007, 445-446) and Jonas Olson (2011 and 2014, chapter 9). ${ }^{24}$ This is because the nonrealist cognitivists and the conservationist moral error theorists would, at this point, accept all the same first-order normative and metaethical theses and only those.

Both non-realist cognitivists and conservationist moral error theorists believe that we have reasons to avoid future agony, and they also agree that we should continue to hold this belief. They furthermore both accept that this belief is, as a psychological state, a genuine belief state with the mind-to-world direction of fit and that it has irreducible normative content. Both sides additionally share the view in moral metaphysics according to which the external reality does not contain a normative fact that we have reasons to avoid future agony. The non-realist cognitivists and the conservationist moral error theorists can furthermore agree on what they should say about the truth of the belief that we have reasons to avoid future agony. If the truth predicate is understood in the deflationist transparent fashion, then both sides will be happy to believe that it is true that we have reasons to avoid future agony given that this is the same belief as the belief that we have reasons to avoid future agony, which they both already hold. They both also deny that it is true in the further correspondence sense that we have reasons to avoid future agony. ${ }^{25}$

If the non-realist cognitivists thus accept a deflationist theory of the truth predicate and, at the same time, deny that there are (inflated) normative facts, then they can no longer

\footnotetext{
${ }^{24}$ For the threat that Parfit's view collapses into moral error theory more generally, see Olson (forthcoming, Sect. 3.1).

${ }^{25}$ It could be suggested that we should understand the disagreement between conservationist moral error theory and non-realist cognitivism as a disagreement about whether the actual truth predicate is used in the deflationary way (non-realist cognitivism) or the correspondence theory way (conservationist moral error theory). This would be an odd place for the metaethical disagreement. After all, the defenders of the two views would now agree in moral semantics, moral metaphysics and moral psychology but only disagree about how the truth predicate functions generally in our linguistic community.
} 
distinguish their own view from the conservationist versions of moral error theory as both views end up accepting all the same normative and metaethical theses and only those. I, however, assume that the non-realist cognitivists will not be able to accept this result, but rather, they will instead insist that they genuinely disagree with the conservationist moral error theorists because their own view is substantially different from that version of moral error theory. The non-realist cognitivists will want to argue that their metaethical view is correct and also that the conservationist versions of moral error theory fail exactly for the same reasons as all other versions of moral error theory (see Sect. 1 above).

The question then becomes: how can the non-realist cognitivists distinguish their metaethical view from the conservationist versions of moral error theory? As far as I can see, the non-realist cognitivists must, at this point, reject the deflationist theories of the truth predicate and, instead, endorse some more substantial theory of the property of being true. This theory of truth could not, of course, be a correspondence theory of truth for the reasons already explained, but rather, it would have to be a view based on some other substantial property of normative beliefs and statements. The non-realist cognitivists would then be able to understand their disagreement with the conservationist moral error theorists in terms of this property. They could argue that certain normative beliefs such as the belief that we have reasons to avoid future agony have this substantial property that constitutes normative truth even when the conservationist moral error theorists are committed to denying that this belief has that property. ${ }^{26}$ I do not see what other means that the non-realist cognitivists would have for distinguishing their view from conservationist versions of moral error theory, and if this is right, then, the non-realist cognitivists cannot endorse deflationist views of the meaning of the truth predicate. The following sections will then consider what alternatives that the nonrealist cognitivists would have at this point and why these alternative substantial theories of truth will be problematic for them.

\section{Coherentism and Pragmatism}

This section considers two less popular theories of truth, coherentism and pragmatism, which too understand truth as a relational property. However, instead of being a relation between the truth-bearing propositions and reality, according to these views, truth is a relation between those propositions and either (i) other believed propositions or (ii) beneficial consequences. This section focuses on how these views lead to objectionable first-order relativism about normative truths.

Coherentists begin from the idea that a proposition $\angle \mathrm{P}>$ is true if and only if, and just because, the belief that $p$ belongs to the maximally coherent set of beliefs. ${ }^{27}$ For wellknown reasons, maximal coherence here cannot merely consist of logical consistency,

\footnotetext{
${ }^{26}$ One place where this disagreement becomes evident is the reasons that we have for continuing to hold our normative beliefs. The conservationist error theorists claim that these reasons are prudential reasons (Olson 2014, sec. 9.3), whereas the non-realist cognitivists argue instead that the truth of certain normative propositions itself gives us a reason to hold the beliefs in question. Given that the notion of truth that does this explanatory work could not be merely deflationary truth (Lynch 2009, chapter 6), here too, the non-realist cognitivists would have to commit themselves to a more substantial property of being true.

${ }^{27}$ Canonical defences of coherentism include Blanshard (1939), Bradley (1914) and Walker (1989). For overviews, see Engel (2002, 26-29), Künne (2003, 381-393) and Young (2013). In metaethics, a coherentist theory of normative truth has been explicitly defended by Dorsey (2012) and Lynch (2009, 164-184).
} 
but rather, it must also include (i) comprehensiveness of the belief set, (ii) justificatory connections between the set's members and (iii) being controlled by our sensory perceptions (Künne 2003, 382-385). ${ }^{28}$

Let us then, for the sake of an argument, assume that $S_{1}$ is the maximally coherent set of beliefs. $S_{1}$ need not even be a set of beliefs picked out from all the beliefs that we all currently actually hold. Rather, it could instead be (i) the maximally coherent set of beliefs chosen from all the beliefs that people will hold at some point in the actual future or even (ii) the hypothetical maximally coherent set of beliefs of all those beliefs which people would have at the end of indefinitely long idealized process of inquiry. Let us finally stipulate that the belief that we have reasons to avoid future agony belongs to $S_{1}$. In this situation, the non-realist cognitivists who are coherentists about truth could explain the truth of the proposition <WE HAVE REASONS TO AVOID FUTURE AGONY> in terms of the stipulated form of coherence.

The problem is that this coherentist proposal is inconsistent with Parfit's understanding of normative truths. According to him, normative truths are necessary truths and thus independent of human judgments, beliefs, desires and other attitudes (Parfit 2011, vol. 1, 129 and vol. 2, 307, 326, 489, 643 and 749). Normative truths would not have these features if coherentism about truth were true. Instead of $S_{1}$, some other set of beliefs $\mathrm{S}_{2}$ could have been the maximally coherent set. This is because we all could have had different beliefs than the ones that we actually have now and the future people also could come to have different beliefs than the ones that they actually will have. It is even the case that people at least hypothetically could converge on having any one set of beliefs from a number of different alternatives at the end of indefinitely long idealized process of inquiry. ${ }^{29}$

If some other set $\mathrm{S}_{2}$ then could have been the maximally coherent one, this entails that some other normative propositions could have been true. Thus, on this view, normative truths could have turned out to be different from what they are and therefore we could have lacked reasons to avoid future agony. This is why coherentism leads to relativism: what the normative truths are modally co-varies with and thus depends on which set of beliefs happens to be the maximally coherent one currently, in the future, or at the hypothetical end of the idealized reasoning.

The cost of using coherentism about truth to understand normative truth is then having to give up the idea that normative truths are necessary truths. Accepting coherentism thus commits the non-realist cognitivists to first-order relativism about reasons, which makes non-realist cognitivism less attractive to those who share Parfit's basic conviction that whether we have reasons to avoid future agony cannot depend on

\footnotetext{
${ }^{28}$ The main problem is that understanding coherence merely to require logical consistency makes truth too "cheap". Consider a case in which we have a new statement that Q, which we are inclined to believe in the situation we are in and an old set of beliefs $\{\mathrm{P}$, If $\mathrm{P}$ then not-Q, ... $\}$. In this case, there are two ways of making the new statement logically consistent with our old set of beliefs: we can either believe that not-Q and keep our old beliefs or adopt the belief that $\mathrm{Q}$ and give up our old belief that if $\mathrm{P}$ then not-Q. If we understood coherence as mere lack of self-contradiction, then in this case, there would be two equally maximally coherent sets of beliefs as a consequence. Here, we therefore cannot understand truth as merely logical consistency because at least one of these sets must contain a false belief - either Q or not-Q must be true but not both.

29 The question here is not the controversial one about whether there actually will be normative convergence at the end of the idealized inquiry (see Boyd 1988, 213). Rather, the claim in question here is the much weaker one: if most people do actually happen to converge on a single set of beliefs, even in that case, they all could have at least, in principle, converged on a different set. There is no reason to doubt this weaker modal thesis.
} 
our attitudes. Despite this, a combination of non-realist cognitivism and coherentism about truth remains available for those who are willing to endorse the first-order relativist implications. ${ }^{30}$

The same can be said about the combination of non-realist cognitivism and pragmatism about truth. According to a crude version of pragmatism, the proposition that $\mathrm{p}$ is true if and only if, and just because, the belief that $p$ is useful in the sense of having beneficial consequences through the actions of the believer. ${ }^{31}$ Thus, the truth of the proposition <WE HAVE REASONS TO AVOID FUTURE AGONY> would, on this view, consist of the belief in these reasons leading to successful actions.

This basic pragmatist view too leads to relativism. ${ }^{32}$ Whether a belief with a certain proposition as its contents leads to successful action depends on the circumstances of the believer and what other beliefs and desires she has. One consequence of pragmatism would thus be that normative truths would not be necessary truths and hence independent of human judgments, attitudes and practices. In most situations, believing that we have reasons to avoid future agony presumably leads to success, and yet, in other exceptional situations, having this belief could be harmful. Whether it is true that we have reasons to avoid future agony would thus depend on our circumstances and what other attitudes that we have. Thus, a combination of non-realist cognitivist and coherentism is again not available for those who think that normative truths are necessary truths. ${ }^{33}$

\section{Epistemic Theories of Truth and Primitivism}

This leaves us with epistemic theories of truth and primitivism. This final section will argue that epistemic theories of truth (i) collapse non-realist cognitivism to some other metanormative position, (ii) commit non-realist cognitivism to some other theory of truth in a problematic way, or (iii) lead to a vicious regress. This means that the only alternative for Parfit and other non-realist cognitivists will be primitivism about truth. I will finish off by outlining some of the costs of this remaining alternative.

\footnotetext{
${ }^{30}$ Some metaethicists could, in principle, endorse this combination of non-realist cognitivism, coherentism and relativism. See, for example, Driver (forthcoming) and Street (2012). There is one way in which nonrealist cognitivism combined with coherentism about truth could be made to support necessary normative truths. The idea would be to claim that whichever normative truths obtain in any possible world is a matter of which normative beliefs happen to belong to the maximally coherent set in the actual world. The cost of this move is that it makes the maximally coherent set of normative beliefs in the actual world one that could not have been false. The theoretical cost of guaranteeing necessary normative truths in this way thus is infallibility. ${ }^{31}$ This basic formulation of pragmatism about truth follows Engel $(2002,34)$. Even if it is close to James $(1907,106)$, it is not clear whether any actual pragmatist has ever accepted the view in this form.

${ }^{32}$ See Engel (2002, 35). Some pragmatists endorse this consequence (see, e.g., Rorty (2009 [1979], 373-379).

33 There are also more sophisticated forms of pragmatism, but it is unlikely that the non-realist cognitivists could make use of them to give an account of normative truth. This is because these views are more naturally understood as (i) explanations of how the importance of truth is connected to practical ideals and action (James (1907, 93), (ii) accounts of beliefs in terms of dispositions to act (Peirce 1905, 168), (iii) theories of belief contents in terms of their utility conditions (Ramsey 1927, 159), (iv) suggestions that the usefulness of beliefs depends on their truth (James 1907, 98-99) or (v) as epistemic theories of truth (Peirce 1901, 718-720).
} 
Epistemic theories of truth begin from the observation that domains of discourse are governed by their internal epistemic norms. ${ }^{34}$ These norms fix when you are warranted to assert the sentences that express the propositions of the discourse. They thus determine when you have sufficient evidence for making assertions in the given discourse. In any area of discourse, there is obviously a difference between having evidence that justifies asserting a proposition and the truth of that proposition. This is because it is possible to have sufficient warrant for asserting a false proposition given the misleading evidence you have.

At this point, it has been suggested that, even if there is a difference between truth and warrant, we can use the epistemic norms of a discourse to define a more demanding epistemic property of propositions than merely warranted assertibility and then use that property to give an account of the nature of truth in the discourse (Putnam 1981, 55). I will focus here on Crispin Wright's (1992) proposal. Wright uses the epistemic norms of a discourse to define an epistemic property of superassertibility (Wright 1992, 44 48). A proposition is superassertible if and only if, and just because, (i) there exists an accessible state of information such that (ii) it would warrant asserting that proposition and (iii) this warrant would survive "arbitrarily close scrutiny of its pedigree and arbitrarily extensive increments to or other forms of improvement of our information" (Wright 1992, 48). Wright then argues that, because superassertible propositions have all platitudinous qualities of true propositions (see below), at least in some domains, we can understand truth to be realized by superassertibility (Wright 1992, 48-61).

Could the non-realist cognitivists then understand the truth of normative propositions in terms of superassertibility ${ }^{35}$ Given that superassertibility is a metaphysically lightweight epistemic property, this proposal would fit Parfit's thought that normative truths do not have metaphysical implications (Parfit 2011, vol. 2, 486-487; Parfit 2015, 14-15). Yet, unfortunately, the combination of non-realist cognitivism and an epistemic theory of truth leads to a trilemma.

The problem is the condition (ii) in the definition of superassertibility. It sets a normative condition for superassertibility. A proposition is superassertible in part because information exists that would warrant asserting the proposition. However, having warrant for making an assertion amounts to having justification and good reasons for doing so, and justification and reasons are inherently normative notions. We must then consider the normativity that is built right into the definition of superassertibility. How could the non-realist cognitivists understand it?

The non-realist cognitivists have three bad alternatives here. Firstly, they could use some other metanormative theory to understand epistemic normativity (such as a version of noncognitivism, naturalism, or metaphysical non-naturalism). This would make non-realist cognitivism a more restricted theory of normativity: it would not be an account of all normativity but rather perhaps only of normativity in the domain of practical reasons and other related normative properties. ${ }^{36}$ The main challenge for the non-realist cognitivists would, however, be to explain why their own objections to other metaethical accounts of

\footnotetext{
${ }^{34}$ For canonical defences, see Dummett (1978 and 1993), Putnam (1981 and 1983) and Wright (1992 and 2003). For overviews, see Engel (2002, chapter 3) and Künne (2003, 404-453)

${ }^{35}$ Metaethical views similar to this have been explored by Putnam (2004), Scanlon (2014) and Wright (2003, essays 7 and 8 ).

${ }^{36}$ I borrow the terminology of restricted accounts from Street (2008, 208-209). Cuneo (2007, chapter 2) pursues the parallel between epistemic reasons and practical reasons.
} 
practical normative reasons do not also apply to the corresponding metanormative views about warranted assertion (see footnotes 5-7 above). For example, if naturalism about practical reasons fails because of the so-called missing property objection, then, other things being equal, naturalism about epistemic reasons suffers from the same problem.

This means that the non-realist cognitivists will, in all likelihood, adopt a non-realist cognitivist theory also of the epistemic normativity that is built into superassertibility. According to this proposal, there are some necessary truths about what information warrants asserting propositions about practical reasons where these truths are both necessary and lack any metaphysical implications. These normative epistemic truths would then determine which propositions about practical reasons are superassertible and hence minimally true. This allows us to ask again: of what does the truth of the relevant normative epistemic propositions about warranted assertion consist?

Here, the non-realist cognitivists can either again endorse an epistemic account of truth or adopt some other theory of truth. If my arguments so far have been along the right lines, they also provide grounds for thinking that non-realist cognitivists cannot, at this stage, adopt any of the previously discussed theories of truth. For example, because the non-realist cognitivists do not believe in a normative reality, for them, the truth of normative propositions about epistemic warrant cannot consist of correspondence to an epistemic normative reality any more than normative truth could consist of correspondence in the context of practical reasons. And, the same goes for deflationism, coherentism and pragmatism.

This means that the non-realist cognitivists who want to endorse an epistemic account of the truth of the normative propositions about practical reasons must also accept a similar account of the truth of the normative propositions concerning warranted assertion. Thus, she must also think that the truth of the proposition <INFORMATION $S$ WARRANTS ASSERTING THAT WE HAVE REASONS FOR AVOIDING FUTURE AGONY> consists of its superassertibility or some other related normative epistemic property.

This suggestion leads to a regress. In order for the previous proposition <INFORMATION S WARRANTS ASSERTING THAT WE HAVE REASONS FOR AVOIDING FUTURE AGONY> to be superassertible and thus minimally true, it must also be true that some further information $\mathrm{S}^{*}$ would warrant asserting that proposition. Of what does the truth of the proposition <INFORMATION S* WARRANTS ASSERTING THAT INFORMATION S WARRANTS ASSERTING THAT WE HAVE REASONS FOR AVOIDING FUTURE AGONY> then consist? If it consists of superassertibility too, then it must again be true that some further information $\mathrm{S}^{* *}$ warrants asserting that $\mathrm{S}^{*}$ warrants asserting that $\mathrm{S}$ warrants asserting a proposition about our reasons. And, again, of what does the truth of this third-order epistemic normative claim consist? Here, the non-realist cognitivist would be committed to there being infinitely many states of information that would warrant asserting propositions about warranted assertion on the lower levels. ${ }^{37}$ It is not easy to see how there could be so many states of information.

\footnotetext{
${ }^{37}$ It could be suggested that the very same piece of information could always warrant the proposition about epistemic warrant on the previous level within the infinite regress. Theoretically, this could be the case, but it is difficult to see just what the relevant information could be information about. This information would, after all, have to be (i) accessible to ordinary inquirers and (ii) independent of human judgments and attitudes, and (iii) finally, the information that warrants a given normative statement would also have to be conceptually independent of the statement that is being warranted. These conditions rule out comprehensive information states and the original statement itself from playing the required warranting role.
} 
We can then summarize the trilemma in the following way. The question is: how can the non-realist cognitivist give an account of this epistemic normativity built into warranted assertion, which could be used to give an epistemic account of normative truth? I have argued that she can here (i) adopt a different metanormative theory, (ii) understand this normativity in the non-realist cognitivist way but adopt a non-epistemic theory of the truth of the relevant normative epistemic propositions or (iii) also offer an epistemic account of the truth of the epistemic normative propositions. If the non-realist cognitivists go for (i), they have to deal with their own objections to the alternative metaethical theories. If they go for (ii), they have to deal with my objections to combining non-realist cognitivism with the other theories of truth. And, finally, (iii) leads to an infinite regress.

As a consequence, non-realist cognitivists are forced to accept the only account of normative truth left: primitivism. According to primitivism, the concept of truth is a fundamental, unanalysable and undefinable concept exactly in the same way as the concept of practical reasons is for Parfit. ${ }^{38}$ However, the previous thesis is not enough for the non-realist cognitivists' purposes. This is because a fundamental, unanalysable concept of truth is compatible with the property of truth being a relational property, a relation between the truth-bearing propositions and a chunk of reality (correspondence theories), other propositions (coherentism) or beneficial consequences (pragmatism) (Asay 2013, 503-504). We have already seen that non-realist cognitivists cannot accept these views, and so, the non-realist cognitivists must also accept primitivism about the property of truth.

This means that the non-realist cognitivists' property of truth would need to be a non-relational, "monadic" property of some normative propositions. This property would need to be a metaphysically robust property - a genuine stance-independent difference between the normative propositions that have it and those that lack it. This is because the standard ways to make the truth property metaphysically lightweight rely on either deflationism or epistemic views about truth, and these views, we have seen, are not available for the non-realist cognitivists. Secondly, it also seems likely that this truth property could not be a natural property of propositions. Propositions are standardly understood as either sets of possible worlds or as some kind of structured semantic entities. ${ }^{39}$ It is difficult to see how either of these types of entities could have non-relational properties that were empirically observable, causally efficacious and part of the subject matter of sciences.

As a consequence, the non-realist cognitivists have to claim that some normative propositions have a non-relational, monadic, metaphysically robust, non-natural property of being true. Presumably, this property would also be a simple property that does not consist of having any other non-relational, metaphysically robust and non-natural properties. It would furthermore be easy to understand this property as a sui generis property - as a property of its own unique kind.

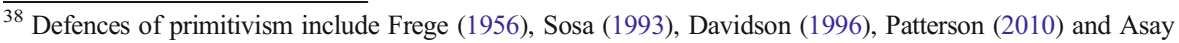
(2013). For an overview, see Künne (2003, 15-18). For Parfit on the concept of reasons, see Parfit (2011, vol. $2,266)$. Skorupski $(2006,33)$ seems to endorse explicitly primitivism about truth in combination with nonrealist cognitivism.

${ }^{39}$ For canonical formulations, see Montague (1960) and Kaplan (1989 [1977], 494 495).
} 
The previous non-relational property of truth now appears to be very much like the metaphysical non-naturalists' normative properties. G.E. Moore is often thought to have defended the view that intrinsic value is a simple, non-relational, metaphysically robust, sui generis non-natural property (Moore 1903 [1993], 66-72). ${ }^{40}$ Now, the nonrealist cognitivists are forced to claim that truth as a property of normative propositions shares these same features. At this point, it becomes difficult to understand what motivation there could be to prefer non-realist cognitivism over metaphysical nonnaturalism. The original motivation for doing so was supposed to be that the normative properties posited by metaphysical non-naturalism would be "too queer to be compatible with a scientific world view" (Parfit 2011, vol. 2, 486 and 465). However, now it seems likely that non-realist cognitivists are committed to an equally queer property of truth that is equally incompatible with the scientific world view. ${ }^{41}$ This would mean that the non-realist cognitivists' own argument against metaphysical non-naturalism applies against their own view, and so, we have not been offered any reason to prefer nonrealist cognitivism over metaphysical non-naturalism.

The second problem is that there are platitudinous things that we know about truth. It is controversial what these core truisms about truth are, but many people have claimed that they consist of the following (Engel 2002, 67; Lynch 2009, 7-19; Putnam 1981, 55; Wright 1992, 39 and 49):

- Truth does not come in degrees.

- Truth is a timeless notion.

- No proposition can be both true and false.

- A proposition is true when things are as the proposition represents them as being.

- Some beliefs can be true but not warranted, and some can be warranted but not true.

- Truth is an appropriate goal of inquiry.

- Whatever attitude we take towards a proposition, we are committed to taking the same proposition towards its truth.

- You should assert a sentence that expresses a given proposition only if the proposition is true.

- Truth is preserved in valid arguments.

These widely accepted platitudes give us general information both about the property of truth itself and also about how that property is related to other important philosophical notions such as facts, warrant, assertion, inquiry, validity and so on. We then want the theories of truth to explain why true propositions have the properties which the core truth-truisms attribute to them (Lynch 2009, 18). Such explanations are, in fact, what the defenders of the competing views about truth (correspondence theories, coherentism, epistemic theories...) are attempting to provide.

\footnotetext{
${ }^{40}$ For a different interpretation, see Dreier (2006).

${ }^{41}$ It is true that a significant source of the Mackian worries about metaphysical queerness of normative properties is the required objective prescriptivity of these properties (see Mackie 1977, 38-39). It could then be argued that the primitive monadic property of being true would not need to be queer in this way because such a property would not need to be objectively prescriptive. The problem is that, even if this property would not need to contain any "to-be-doness", it would need to contain an equally suspect quality of "to-bebelievedness" to explain why we ought to believe normative truths. It could also be argued that even without this additional prescriptive quality, the monadic truth property would already be metaphysically suspect because it would have to be an additional element of reality outside the causal network of the natural world.
} 
The problem with the type of primitivism about truth which the non-realist cognitivists seem compelled to accept is that its defenders will not have any resources to explain the platitudinous features of true propositions. When it comes to some of those features, the nonrealist cognitivists can at most stipulate that the truth property has them. For example, the non-realist cognitivists can only state that the simple non-relational, metaphysically robust, non-natural sui generis property is also a timeless property that does not come in degrees, but nothing we know of that property can be offered to explain why this is the case.

This problem gets even worse, because this strategy of stipulating what the truth property is like cannot be used to deal with the platitudes that connect the truth property to the other philosophically interesting notions. If truth is the appropriate goal of inquiry, functions as the norm of assertion and is separate from mere warrant, surely, there must be some explanation for why this is the case. Yet, nothing about the posited simple non-relational, metaphysically robust, non-natural sui generis property can shed any light on why truth would be related to inquiry, assertion and warrant in these ways. This is the second theoretical cost of adopting the relevant kind of primitivism about the truth property: adopting that view about truth leaves the non-realist cognitivists with no resources to explain the type of role that truth plays in relation to other central philosophical notions. ${ }^{42}$

\section{Conclusion}

In this article, I have focused on Parfit's non-realist cognitivism. It endorses stance-independent normative truths that do not have any metaphysical implications. I have tried to argue that the defenders of this view cannot make sense of what the truth of these normative truths consists by relying on the standard theories of truth: correspondence theories, forms of deflationism, coherentism, pragmatism and epistemic theories of truth. This means that they would need to posit a primitive, simple, non-relational, metaphysically robust, non-natural sui generis property of truth. At the end of the previous section, I outlined some of the significant costs of this last alternative. ${ }^{43}$

\footnotetext{
${ }^{42}$ Given that primitivists might explicitly hold that the platitudinous features of truth cannot be explained, it could be suggested that this second objection to the combination of non-realist cognitivism and primitivism about truth begs the question. We can, however, rely here on abductive reasoning without begging any questions. Many other metaethical frameworks can explain the platitudinous features of true normative beliefs by relying on the features of correspondence and superassertibility. We thus have a good reason to prefer these theories due to their superior explanatory power: they can explain things about truth which the non-realist cognitivists who endorse primitivism cannot explain. This argument to the best explanation begs no questions. ${ }^{43}$ Parfit seems to suggest that mathematical and logical truths and normative truths should be understood in the same way (Parfit 2011, vol. 2, 479-480). It could then be asked whether my arguments entail that the nature of mathematical and logical truths is also incompatible with the standard theories of truth and hence only compatible with problematic forms of primitivism. I intend my arguments to have no such consequences. First of all, we could be metaphysical realists about mathematics and logic and thus understand the truths in these domains in terms of correspondence to a mathematical and logical reality. We could also be expressivists about mathematics and logic and understand truth in these domains in the deflationary way. Finally, everything that is said in this paper is also compatible with different forms of conventionalism and intuitionism that regard mathematical and logical truth to be either a matter of coherence or provability, which is an epistemic property. The arguments which I have used against combining non-realist cognitivism and the standard theories of truth after all in many cases draw from the unique features of the normative domain.
} 
I hope that this critical investigation presents non-realist cognitivists with a genuine challenge. They are required to give a plausible account of normative truth, which they have not yet done so far and which will not be a trivial task if my arguments above are correct. This hopefully illustrates how Parfit's metaethical view is at least in one respect problematic. Whether we should reject this view for this reason, of course, depends on the other costs and benefits of the view and how all these costs and benefits compare with the theoretical costs and benefits of the other alternatives.

Open Access This article is distributed under the terms of the Creative Commons Attribution 4.0 International License (http://creativecommons.org/licenses/by/4.0/), which permits unrestricted use, distribution, and reproduction in any medium, provided you give appropriate credit to the original author(s) and the source, provide a link to the Creative Commons license, and indicate if changes were made.

\section{References}

Alston, W. (1996). A realist conception of truth. Ithaca: Cornell University Press.

Anscombe, G. E. M. (1957). Intention. Oxford: Basil Blackwell.

Asay, J. (2013). Primitive truth. Dialectica, 67(4), 503-519.

Austin, J. L. (1970[1950]). Truth. In his Philosophical papers (pp. 117-133). Oxford: Oxford University Press.

Blackburn, S. (1993). Essays in quasi-realism. Oxford: Oxford University Press.

Blackburn, S. (1998). Spreading the word. Oxford: Oxford University Press.

Blackburn, S. (2016). All souls night. Singer, 2016.

Blanshard, B. (1939). The nature of thought. London: Allen \& Unwin.

Boyd, R. (1988). How to be a moral realist. In G. Sayre-McCord (Ed.), Essays on moral realism (pp. 181228). Ithaca, NY: Cornell University Press.

Bradley, F. H. (1914). Essays on truth and reality. Oxford: Clarendon Press.

Brink, D. (1989). Moral realism and the foundations of ethics. Cambridge: Cambridge University Press.

Copp, D. (forthcoming). Normative concepts. In Kirchin (forthcoming).

Cuneo, T. (2007). The normative web. Oxford: Oxford University Press.

David, M. (2015). The correspondence theory of truth. Available via The Stanford encyclopedia of philosophy. http://plato.stanford.edu/entries/truth-correspondence/. Cited 16 Feb 2016.

Davidson, D. (1996). The folly of trying to define truth. Journal of Philosophy, 93(6), 263-278.

Dorsey, D. (2012). A puzzle for constructivists and how to solve it. In J. Lenman \& Y. Shemmer (Eds.), Constructivism in practical philosophy (pp. 99-118). Oxford: Oxford University Press.

Dowell, J. and Sobel, D. (forthcoming). Advice for non-analytical naturalists. In Kirchin (forthcoming).

Dreier, J. (2006). Was Moore a Moorean? In T. Horgan \& M. Timmons (Eds.), Metaethics after Moore (pp. 191-208). Oxford: Oxford University Press.

Driver, J. (forthcoming). How I learned to stop worrying and love contingency”. In Kirchin (forthcoming).

Dummett, M. (1978). Truth and other enigmas. London: Duckworth.

Dummett, M. (1993). Seas of language. Oxford: Oxford University Press.

Engel, P. (2002). Truth. Acumen: Chesham.

Enoch, D. (2011). Taking morality seriously. Oxford: Oxford University Press.

Field, H. (1986). The deflationary conception of truth. In G. MacDonald \& C. Wright (Eds.), Fact, science and morality (pp. 55-117). Oxford: Blackwell.

Finlay, S. (2014). Confusion of tongues. Oxford: Oxford University Press.

Frege, G. (1956). The thought: a logical inquiry. Mind, 65(259), 289-311.

Gibbard, A. (1990). Wise choices, apt feelings. Cambridge, MA: Harvard University Press.

Gibbard, A. (2003). Thinking how to live. Cambridge, MA: Harvard University Press.

Gibbard, A. (2016). Parfit on normative properties and disagreement. Singer, 2016.

Grover, D. (1992). A prosentential theory of truth. Princeton: Princeton University Press.

Hornsby, J. (1997). Truth: the identity theory. Proceedings of the Aristotelian Society, 97, 1-24.

Horwich, P. (1990). Truth. Oxford: Blackwell. 
Jackson, F. (1998). From metaphysics to ethics. Oxford: Oxford University Press.

Jackson, F. (2016). In defence of reductionism in ethics. Singer, 2016.

James, W. (1907). Pragmatism. New York: Longmans and Green.

Joyce, R. (2001). The myth of morality. Cambridge: Cambridge University Press.

Kaplan, D. (1989 [1977]). Demonstratives. In J. Almog, J. Perry, \& H. Wettstein (Eds.), Themes from Kaplan (pp. 481-564). Oxford: Oxford University Press.

Kirchin, S. (forthcoming). Reading Parfit: on what matters. London: Routledge.

Künne, W. (2003). Conceptions of truth. Oxford: Oxford University Press.

Laskowski, N. (2015). Non-analytical naturalism and the nature of normative thought: a reply to Parfit. Available via Journal of Ethics \& Social Philosophy. http://www.jesp.org/articles/download/nonanalytical-naturalism.pdf. Cited 16 Feb 2016.

Lenman, J. (2011). Naturalism without tears. In Suikkanen and Cottingham (2011, 21-38).

Lynch, M. (2009). Truth as one and many. Oxford: Oxford University Press.

Mackie, J. L. (1977). Ethics-inventing right and wrong. London: Penguin Books.

Markovits, J. (forthcoming). On what it is to matter, and other matters. In Kirchin (forthcoming).

McPherson, T. (2011). Against quietist normative realism. Philosophical Studies, 154(2), 223-240.

Montague, R. (1960). On the nature of certain philosophical entities. The Monist, 53(2), 159-194.

Moore, G.E. (1993 [1903]). Principia ethica, revised edition. Cambridge: Cambridge University Press.

Moore, G. E. (1910 [1953]). Some main problems of philosophy. London: Allen \& Unwin.

Nagel, T. (1996). Universality and the reflective self. In O. O’Neill (Ed.), Christine Korsgaard, The sources of normativity (pp. 200-209). Cambridge: Cambridge University Press.

Olson, J. (2011). Getting real about moral error theory. Oxford Studies in Metaethics, 6, 181-204.

Olson, J. (2014). Moral error theory. Oxford: Oxford University Press.

Olson, J. (forthcoming). The metaphysics of reasons. In Daniel Star (Ed.), The Oxford handbook of reasons and normativity. Oxford: Oxford University Press.

Parfit, D. (2011). On what matters (Vol. 1 \& 2). Oxford: Oxford University Press.

Parfit, D. (2015). On what matters, vol. 3. Forthcoming. Oxford: Oxford University Press. manuscript circulated on 16 Jan 2015.

Patterson, D. (2010). Truth as conceptually primitive. In Cory Wright \& P. Nikolaj (Eds.), New waves in truth (pp. 13-29). Houndsmills: Palgrave MacMillan.

Peirce, C. (1901). Truth and falsity and error. In J. M. Baldwin (Ed.), Dictionary of philosophy and psychology (Vol. 2, pp. 718-720). New York: MacMillan.

Peirce, C. (1905). What pragmatism is. The Monist, 15(2), 161-180.

Pigden, C. (2007). Nihilism, Nietzsche, and the Doppelganger problem. Ethical Theory and Moral Practice, $10,441-456$.

Platts, M. (1979). Ways of meaning. London: Routledge and Kegan Paul.

Putnam, H. (1981). Reason, truth and history. Cambridge: Cambridge University Press.

Putnam, H. (1983). Realism and reason. Cambridge: Cambridge University Press.

Putnam, H. (2004). Ethics without ontology. Cambridge, MA: Harvard University Press.

Railton, P. (2016). Two sides of metaethical mountain. Singer, 2016.

Ramsey, F. (1927). Facts and propositions. Proceedings of the Aristotelian Society, 7, 153-170.

Rorty, R. (2009 [1979]). Philosophy and the mirror of nature. Princeton: Princeton University Press.

Russell, B. (1912). The problems of philosophy. Oxford: Oxford University Press.

Scanlon, T. M. (2014). Being realistic about reasons. Oxford: Oxford University Press.

Schroeder, M. (2007). Slaves of passions. Oxford: Oxford University Press.

Schroeder, M. (2010). Non-cognitivism in ethics. London: Routledge.

Schroeder, M. (2016). What matters about metaethics? In Singer (2016).

Shafer-Landau, R. (2003). Moral realism - a defence. Oxford: Oxford University Press.

Singer, P. (Ed.). (2016). Does anything really matter? Parfit on objectivity. New York: Oxford University Press.

Skorupski, J. (2006). Propositions about reasons. The European Journal of Philosophy, 14(1), $26-48$.

Smith, M. (1994). The moral problem. Oxford: Blackwell.

Smith, M. (2016). Parfit's mistaken metaethics. Singer, 2016.

Sosa, E. (1993). Epistemology, realism and truth. Philosophical Perspectives, 7, 1-16.

Stoljar, D. and Damnjanovic, N. (2010). The deflationary theory of truth. Available via The Stanford encyclopedia of philosophy. http://plato.stanford.edu/entries/truth-deflationary/. Cited 6 Feb 2016.

Strawson, P. (1950). Truth. In his logico-linguistic papers (pp. 190-213). London: Methuen.

Street, S. (2008). Constructivism about reasons. Oxford Studies in Metaethics, 3, 207-245. 
Street, S. (2012). Coming to terms with contingency: humean constructivism about practical reason. In J. Lenman \& Y. Shemmer (Eds.), Constructivism in practical philosophy (pp. 40-59). Oxford: Oxford University Press.

Sturgeon, N. (1988). Moral explanations. In G. Sayre-McCord (Ed.), Essays on moral realism (pp. 229-255). Ithaca, NY: Cornell University Press.

Suikkanen, J., \& Cottingham, J. (Eds.). (2009). Essays on Derek Parfit's On what matters. Oxford: WileyBlackwell.

Walker, R. C. S. (1989). The coherence theory of truth. London: Routledge.

Wedgwood, R. (2007). The nature of normativity. Oxford: Oxford University Press.

Williams, B. (1979). Internal and external reasons. In R. Harrison (Ed.), Rational action (pp. 1-19). Cambridge: Cambridge University Press.

Wittgenstein, L. (1921 [1961]). Tractatus logico-philosophicus. London: Routledge.

Wright, C., \& Pedersen, N. (2010). Truth, pluralism, monism, correspondence. In C. Wright \& N. Pedersen (Eds.), New waves in truth (pp. 205-217). Houndsmills: Palgrave MacMillan.

Wright, C. (1992). Truth \& objectivity. Cambridge, MA: Harvard University Press.

Wright, C. (2003). Saving the differences. Cambridge, MA: Harvard University Press.

Young, J. (2013). The coherence theory of truth. Available via The Stanford encyclopedia of philosophy. http://plato.stanford.edu/entries/truth-coherence/. Cited 16 Feb 2016. 